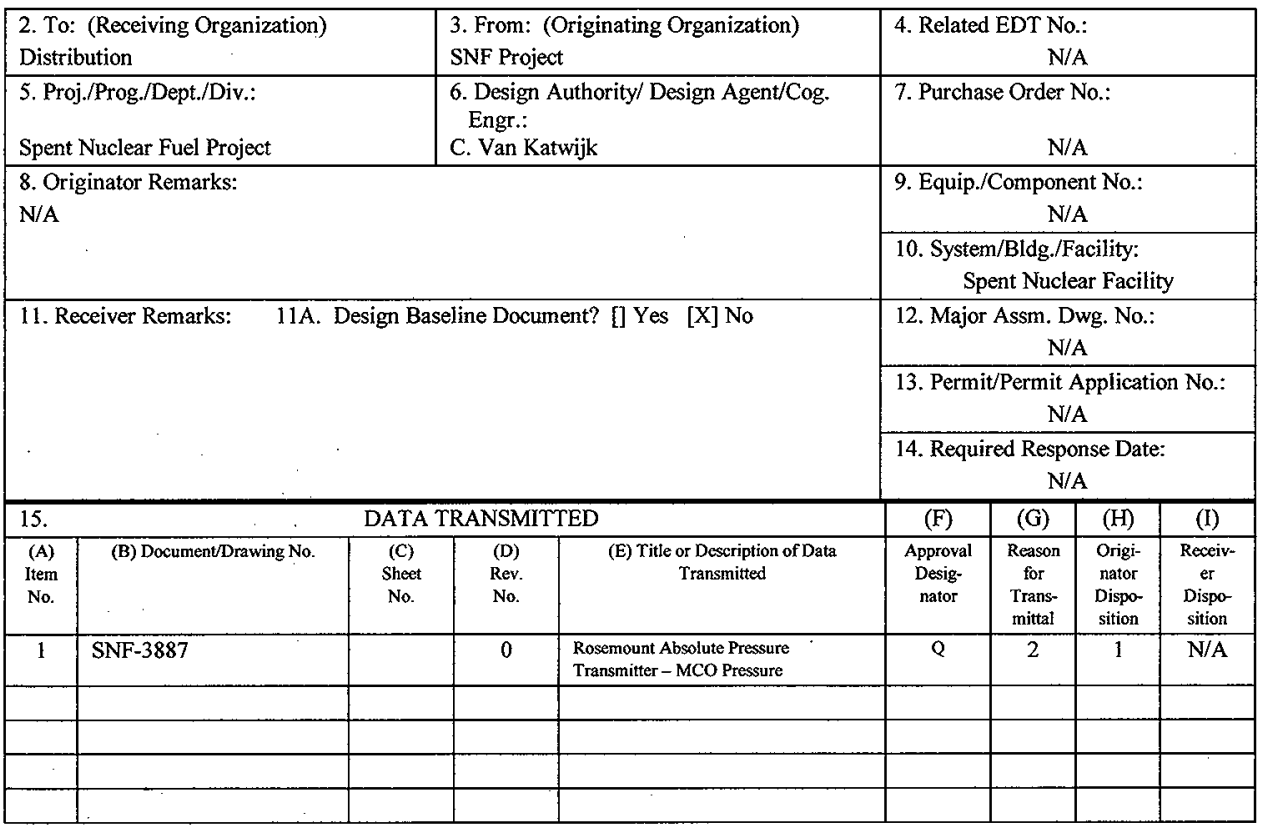

16.

KEY

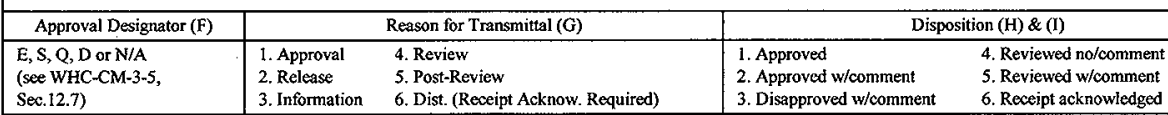

17. SIGNATURE/DISTRIBUTION

(See Approval Designator for required signatures)

\begin{tabular}{|c|c|c|c|c|c|c|}
\hline $\begin{array}{l}\text { (G) } \\
\text { Rea- } \\
\text { son }\end{array}$ & $\begin{array}{l}\text { (H) } \\
\text { Disp. }\end{array}$ & $\begin{array}{llll}\text { (J) Name } & \text { (K) Signature (L) Date (M) MSIN }\end{array}$ & $\begin{array}{l}\text { (G) } \\
\text { Rea- } \\
\text { Son }\end{array}$ & $\begin{array}{c}\text { (H) } \\
\text { Disp. }\end{array}$ & (J) Name & (K) Signature (L) Date (M) MSIN \\
\hline 2 & 1 & Designated Engineer C. Van Katwijk & & & & \\
\hline 2 & 1 & Design Authority R. Whitehurst $(\mathrm{N} / \mathrm{N} \sim 3730) \mathrm{3}$ & & & & \\
\hline 2 & 1 & QA T. D. Hays $\quad$ DO Bam $3 / 30169$ & & & & \\
\hline & & & & & & \\
\hline & & & & & & \\
\hline & & & & & & \\
\hline & & & & & & \\
\hline
\end{tabular}

\begin{tabular}{|c|c|c|c|}
\hline $2=12$ & 19. & (luhe 3130199 & $\begin{array}{l}\text { 21. DOE APPROVAL (if required) } \\
\text { Ctrl. No. } \\
\text { D Approved } \\
\text { Approved w/comments }\end{array}$ \\
\hline $\begin{array}{l}\text { Signature of EDY Date } \\
\text { Originator }\end{array}$ & $\begin{array}{l}\text { Authorized Representative Date } \\
\text { for Receiving Organization }\end{array}$ & $\begin{array}{l}\text { Design Authority/ } \\
\text { Cognizant Manager }\end{array}$ & D Disapproved w/comments \\
\hline
\end{tabular}




\section{Rosemount Absolute Pressure Transmitter - MCO Pressure}

Carl Van Katwijk

Numatec Hanford Co, Richland, WA 99352

U.S. Department of Energy Contract DE-AC06-96RL13200

EDT/ECN: 626260

Org Code: $2 \mathrm{G} 300$

B\&R Code: $39 \mathrm{EW} 40400$
UC: 620

Charge Code: 105559/A000

Total Pages: 4

Key Words: Pressure Transmitter - high resolution, $\mathrm{MCO}$

Abstract: Rosemount Absolute Pressure Transmitter - MCO Pressure

CGI-SNF-D-07-P4-011

TRADEMARK DISCLAIMER. Reference herein to any specific commercial product, process, or service by trade name, trademark, manufacturer, or otherwise, does not necessarily constitute or imply its endorsement, recommendation, or favoring by the United States Government or any agency thereof or its contractors or subcontractors.

Printed in the United States of America. To obtain copies of this document, contact: Document Control Services P P B Box.950, Mailstop H6-08, Richland WA 99352, Phone (509) 372-2420; Fax (509) 376-4989.
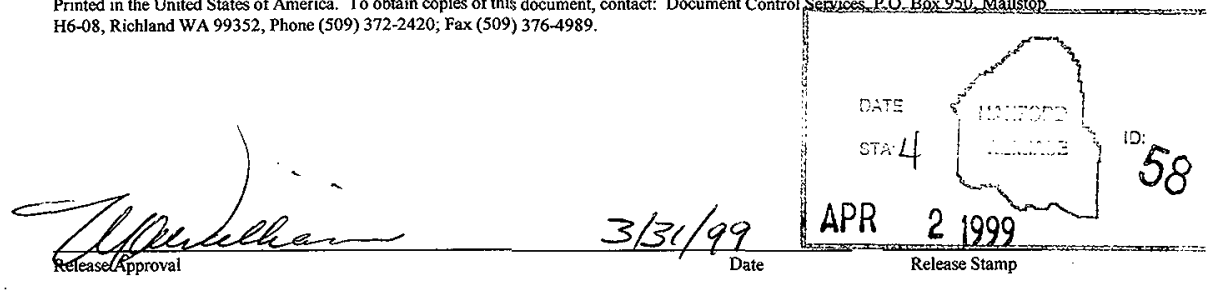

\section{Approved for Public Release}




\begin{tabular}{|l|l|l}
\hline ECN No. NA & CGI No-CGI-SNF-D-07-P4-011 1 of 3 \\
Titte: ROSEMOUNT ABSOLUTE PRESSURE TRANSMITTER-MCO & SNF-3887 \\
\hline PRESSURE & SNF
\end{tabular}

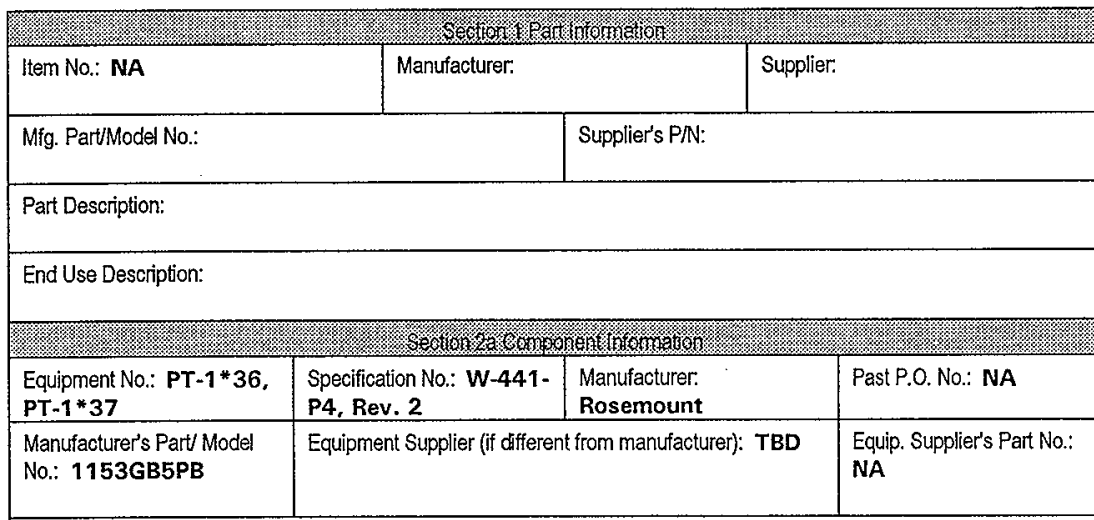

Component Description: Model 1153, series B, absolute pressure transmitter for $\mathrm{MCO}$ and qualified for vacuum service. -14.7 to $12 \mathrm{psig}$ process range. Product data sheet PDS 4302, April 1992.

Provide MCO pressure/vacuum signal to the SCIC.

1. Is the Item available from a catalog from a qualified NQA1 supplier (coordinate with project CG) interface Engineer or BTR)?

[ $X$ ] YES (go to \#2 below)

ouk $12 / 2,198$

( 1 NO (go to procedure step 5.3.2, proceed to dedicate item.)

2. List of Candidate qualified suppliers company name and type contact name phone

Rosemount lnc. (612) $941-5560$

Measurement Division

12001 Technology

Drive, Eden Prairie, MN

55344

3. Recommended Procurement Strategy (coordinate with project CGI interface

Engineer or BTR): Purchase Qualified, W-441-P4, Rev. 2, Appendix L, page L-14, provides a seismic testing plan for these components at a (TBD) seismic spectra. Qualification is to include this seismic testing.

\section{\%1.1\%1.}

1. Question \#1: Is the Item subject to design or specitication requirements that are unique to nuclear facilities or activities?

[X] YES (the ltem is not commercial grade)

1) NO (continue)

2. Question \#2: Is the ltem used in applications other than nuclear facilities or activities?

[ ] NO (the item is not commercial grade)

[X] YES (continue) 
Commercial Grade Item Upgrade Dedication Form ECN No. NA COI No. CGI-SNF-D-07-P4-011

Rev. No. 0

Title: ROSEMOUNT ABSOLUTE PRESSURE TRANSMITTER-MCO PRESSURE

3. Question \#3: Is the Item ordered from manufacturer/supplier on the basis or specifications set forth in the manufacturers catalog?

1 ] NO (the ltem is not commercial grade)

[X] YES (continue)

1 I All three criteria have been satisfied. The ltem meets the definition of commercial grade.

[X] It is determined that the item is not commercial grade. The item is currently specified to be procured as safetygrade from a qualified vendor and no commercial dedication is required.

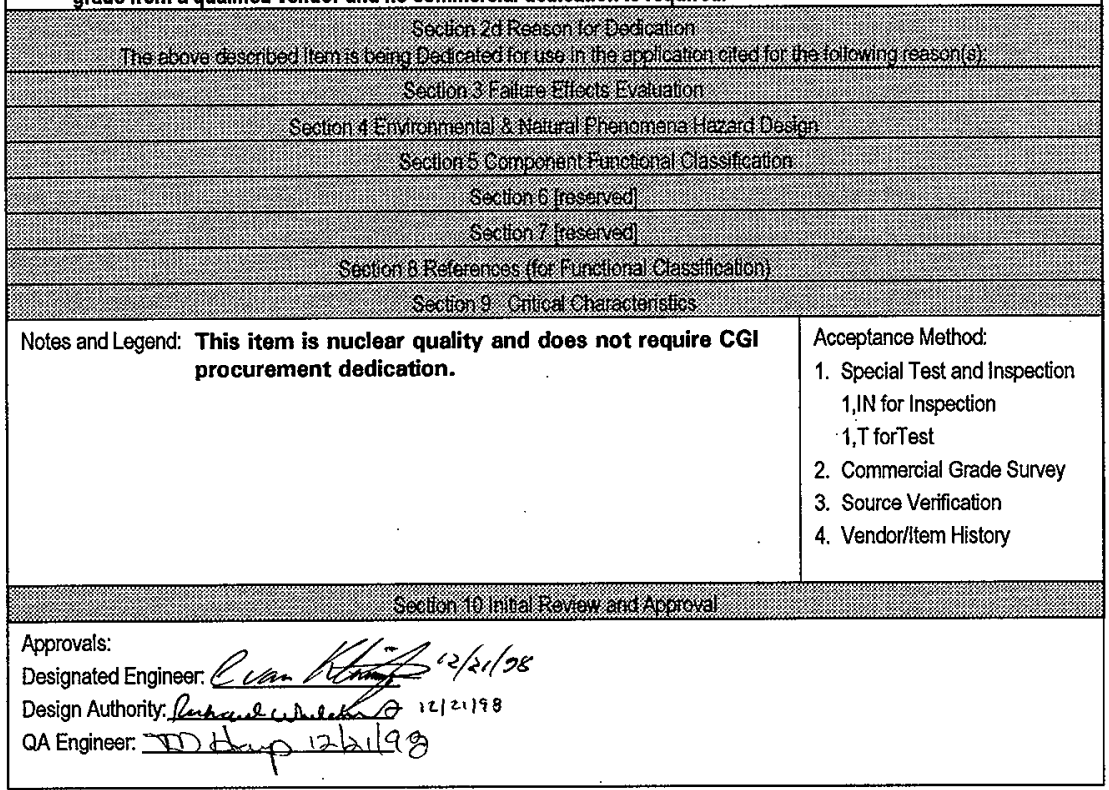




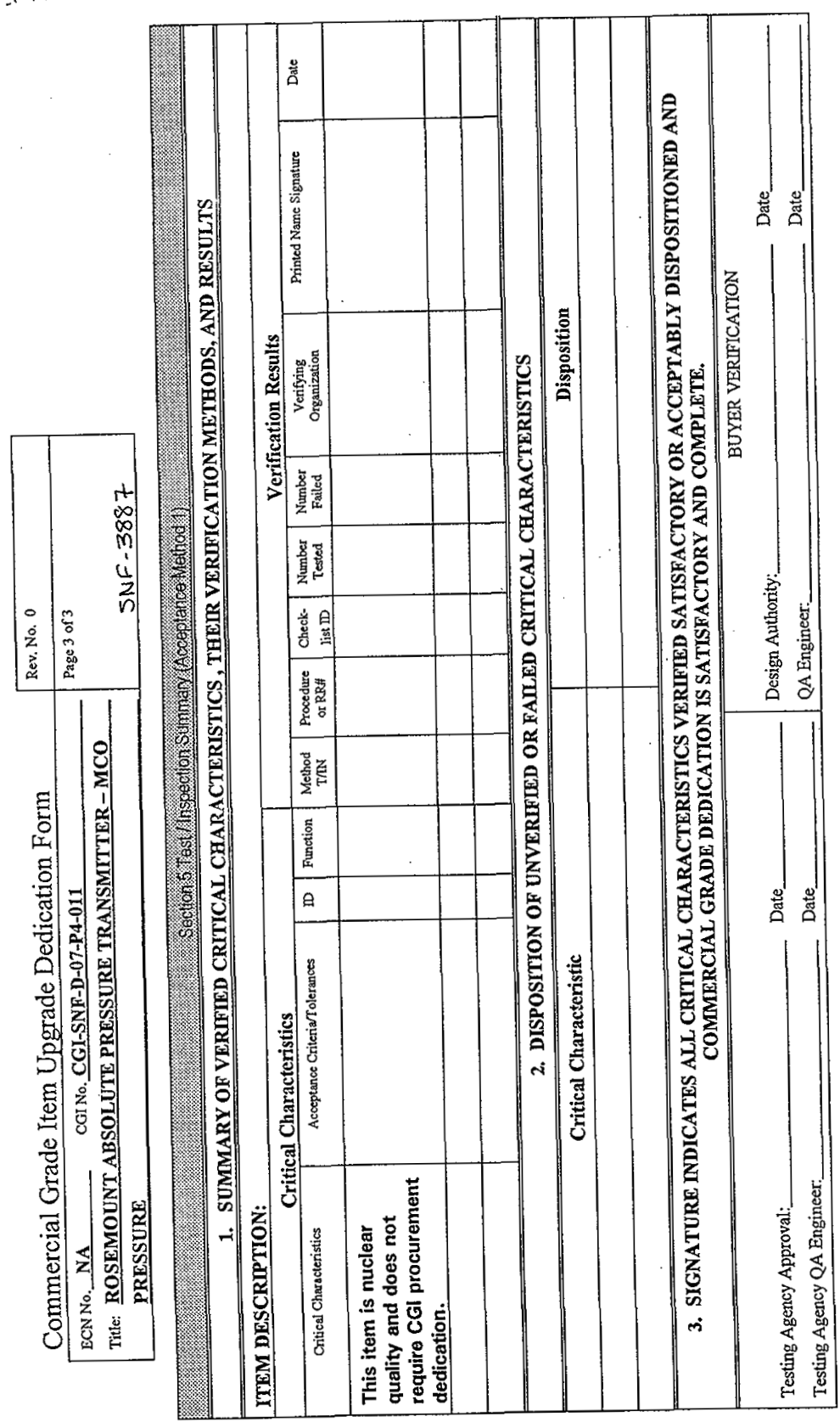

